\title{
Diagnostics and Epidemiology of Colorectal Cancer
}

\author{
Frank T. Kolligs \\ Department of Internal Medicine and Gastroenterology, HELIOS Klinikum Berlin-Buch, Berlin, Germany
}

\author{
Keywords \\ Colorectal cancer - Colon cancer - Screening . \\ Diagnostics · Colonoscopy · Staging
}

\section{Summary}

Colorectal cancer is one of the leading causes of cancerrelated morbidity and mortality. Main risk factors include advanced age, family history, male sex, and lifestyle factors. Screening can reduce incidence and death from colorectal cancer. Therefore, prevention and early detection are crucial in order to detect and remove pre-neoplastic adenomas and to detect cancers at early stages. Colonoscopy, flexible sigmoidoscopy, and fecal occult blood tests are established tools for screening. Newer fecal immunochemical tests reveal higher sensitivities for advanced adenoma and cancer than guaiac-based hemoccult tests. Molecular stool and blood tests as well as virtual colonoscopy and colon capsule endoscopy are promising new developments so far not established as routine instruments for the prevention and early detection of colorectal cancer. Colonoscopy is the method of choice for the diagnosis of colorectal cancer and for adenoma removal. Prognosis is essentially dependent on the tumor stage at the time of the initial diagnosis. Proper staging based on imaging prior to therapy is a prerequisite. In rectal cancer, local staging is an essential requirement for the identification of appropriate candidates for neoadjuvant therapy.

(C) 2016 S. Karger GmbH, Freiburg

\section{Introduction}

Colorectal cancer is the most frequent malignant disease of the gastrointestinal tract, the third most common cancer in men (746,000 cases, $10 \%$ of all cancers), the second most common cancer in women (614,000 cases, $9.2 \%$ of all cancers), and responsible for 600,000 deaths annually worldwide [1].
More than $50 \%$ of all cases occur in more developed regions with wide geographic variation in incidence across the world. Incidence rates vary ten-fold in both sexes worldwide, the highest estimated rates are found in Oceania (age-standardized rates of 44.8 and 32.2 per 100,000 in men and women, respectively), and the lowest in Western Africa (4.5 and 3.8 per 100,000) (fig. 1). For 2012, 345,000 new cases and 152,000 deaths were reported in the European Union [1]. In some regions with previously low incidence rates, e.g. Eastern Europe and East Asia, significantly increasing numbers of colorectal cancer cases have been noted and attributed to changes in risk factors and diet towards a lifestyle common to Western countries [2,3].

In Germany, the lifetime risk of developing colorectal cancer is $6.9 \%$ in men and $5.7 \%$ in women. This corresponds to 1 in 14 men and 1 in 18 women being diagnosed with colorectal cancer within their lifetime, and 1 in 32 men and 1 in 39 women die from colorectal cancer [3]. The risk increases continuously with age. The mean age at diagnosis is 72 years in men and 75 years in women. Age-standardized incidence and mortality rates as well as absolute numbers of new diagnoses have recently been decreasing in Germany. The relative 5 -year survival rate is $63 \%$ in both sexes.

\section{Risk Factors and Inherited Forms}

The individual risk of colorectal cancer is essentially dependent on non-modifiable dispositional factors such as age, sex, and family history as well as the in principle modifiable exposure to risk factors. It is estimated that $30-50 \%$ of the colorectal cancer risk is attributable to lifestyle factors such as smoking, high consumption of red and processed meat, obesity, diabetes, and excessive consumption of alcohol [4].

Age as a risk factor is equally relevant in women and men. More than $50 \%$ of colorectal cancers are diagnosed after age 70 , and only $10 \%$ are diagnosed before age 55 [2]. However, the risk of men developing advanced adenoma or cancer is roughly double that of women $[5,6]$. Furthermore, men develop advanced adenoma and colorectal cancer earlier in their lives than women

\section{KARGER \\ Fax +497614520714

\section{(c) 2016 S. Karger GmbH, Freiburg}

2297-4725/16/0323-0158\$39.50/0
Prof. Dr. med. Frank T. Kollig

Klinik für Allgemeine Innere Medizin und Gastroenterologie HELIOS Klinikum Berlin-Buch

Schwanebecker Chaussee 50, 13125 Berlin, Germany

frank.kolligs@helios-kliniken.de 


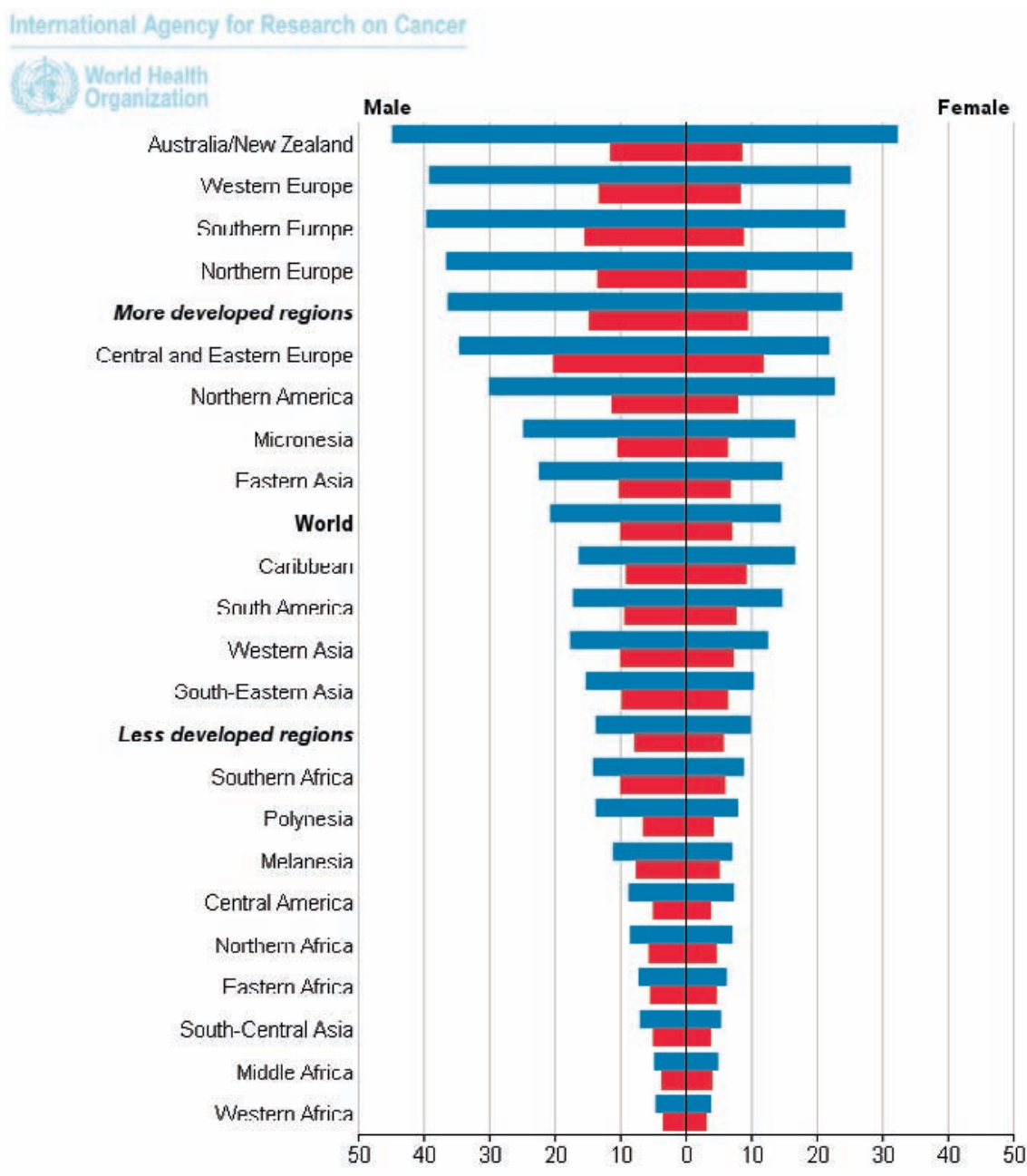

Fig. 1. Estimated age-standardized rates of colorectal cancer worldwide per 100,000 persons [1].

$[6,7]$. A recent study demonstrated that male sex increases the risk to a similar extent as a positive family history of colorectal cancer [8].

\section{Hereditary Colorectal Cancer Syndromes}

Up to one-third of the colorectal cancer risk may be attributable to hereditary factors. Individuals who have biological relatives with a history of colorectal cancer or colorectal adenoma are at increased risk of developing colorectal cancer. The level of risk depends on the degree of kinship, the age at which the index person was diagnosed with colorectal cancer, and the number of relatives affected [9]. Besides familial risk, 3-5\% of colorectal cancer cases are attributable to hereditary syndromes (table 1) [10]. The two most common forms of hereditary colorectal cancer are hereditary nonpolyposis colon cancer (HNPCC, Lynch syndrome) and familial adenomatous polyposis coli (FAP). Both syndromes are autosomal dominant disorders where in HNPCC one allele of a DNA repair gene and in FAP one allele of the tumor suppressor gene adenomatous polyposis coli (APC) are inactivated in the germline. Tumor forma- tion occurs when the function of the remaining gene allele is abrogated by a somatic event. However, only approximately $80 \%$ of individuals with FAP have an affected parent, around $20 \%$ of cases are de novo mutations. Beginning at a mean age of 16 years (range 7-36 years), hundreds and even thousands of colonic adenomas develop [11]. By age 35, 95\% of individuals with FAP have adenomas. Without colectomy, colon cancer is inevitable. Colectomy is usually recommended when more than 20-30 adenomas or multiple adenomas with advanced histology have developed. In contrast, attenuated FAP is characterized by a significant but lower risk for colon cancer than in classical FAP with fewer colonic adenomas which are more proximally located. Cancer occurs later in life. In individuals with attenuated FAP, colectomy may be necessary, but in individuals with a limited number of adenomas, colonoscopy surveillance and polypectomy may be sufficient [12].

Lynch syndrome is attributable to pathogenic variants of the genes MLH1 (50\% of cases), MSH2 (40\%), MSH6 (7-10\%), PMS2 $(<5 \%)$, and EPCAM $(1-3 \%)$, and is characterized by an increased risk for colorectal cancer (lifetime risk 52-82\%, mean age at diagnosis 44-61 years) and cancers of the endometrium (25-60\%, $48-62$ years), ovaries (4-12\%, 42.5 years), stomach (6-13\%, 56 
Table 1. Hereditary colorectal cancer syndromes

\begin{tabular}{|c|c|c|c|}
\hline Syndrome & Precursor lesions & Genetic defect & Disease specifics \\
\hline HNPCC & $\begin{array}{l}\text { development of up to } \\
30 \text { adenomas; typical } \\
\text { molecular pathogenesis } \\
\text { of colorectal cancer }\end{array}$ & $\begin{array}{l}\text { mismatch repair deficiency; } \\
\text { inactivation of DNA repair genes } \\
(M L H 1, M S H 2, M S H 6, P S M 2) \\
\text { or the gene EPCAM; autosomal } \\
\text { dominant inheritance; allele } \\
\text { frequency 1:350-1:1,700 }\end{array}$ & $\begin{array}{l}\text { mean age at cancer diagnosis is } 40 \text { years; } \\
\text { lifetime risk of developing colorectal } \\
\text { cancer } 50-80 \% \text {; frequent development } \\
\text { of syn- and metachronous cancers, e.g. } \\
\text { endometrial, ovarian, gastric, and small } \\
\text { intestinal cancers }\end{array}$ \\
\hline FAP & $\begin{array}{l}\text { development of hundreds } \\
\text { to over a thousand adeno- } \\
\text { matous polyps, classical } \\
\text { adenoma-to-carcinoma } \\
\text { sequence }\end{array}$ & $\begin{array}{l}\text { mutation of the } A P C \text { gene; } \\
\text { autosomal dominant inheritance; } \\
\text { allele frequency 1:10,000 }\end{array}$ & $\begin{array}{l}\text { start of adenoma formation at the age } \\
\text { of } 10 \text {, development of colorectal cancer } \\
\text { from age } 20 \text { onwards; obligate precan- } \\
\text { cerous condition; duodenal and peri- } \\
\text { ampullary adenoma in } 45-90 \%\end{array}$ \\
\hline Attenuated FAP & $\begin{array}{l}\text { development of } 10-100 \\
\text { adenomatous polyps }\end{array}$ & $\begin{array}{l}\text { mutation of the } A P C \text { gene; auto- } \\
\text { somal dominant inheritance }\end{array}$ & $\begin{array}{l}\text { lifetime risk of developing colorectal } \\
\text { cancer }>80 \%\end{array}$ \\
\hline MAP & $\begin{array}{l}\text { development of } 20 \text { to }>100 \\
\text { adenomatous polyps }\end{array}$ & $\begin{array}{l}\text { mutation of the MUTYH gene; } \\
\text { autosomal recessive inheritance }\end{array}$ & $\begin{array}{l}\text { lifetime risk of developing colorectal } \\
\text { cancer }>80 \%\end{array}$ \\
\hline PJS & $\begin{array}{l}\text { development of up to } 20 \\
\text { mostly hamartomatous } \\
\text { polyps }\end{array}$ & $\begin{array}{l}\text { mutation of the STK11 gene; } \\
\text { autosomal dominant inheritance }\end{array}$ & $\begin{array}{l}\text { lifetime risk of developing colorectal } \\
\text { cancer approximately } 40 \% \text {; hyperpig- } \\
\text { mented macules on lips and oral mucosa }\end{array}$ \\
\hline JPS & $\begin{array}{l}\text { development of up to } 5 \text { to } \\
>100 \text { hamartomatous } \\
\text { polyps }\end{array}$ & $\begin{array}{l}\text { mutation of the SMAD4 or the } \\
B M P R 1 A \text { gene; autosomal } \\
\text { dominant inheritance }\end{array}$ & $\begin{array}{l}\text { lifetime risk of developing colorectal } \\
\text { cancer } 40-70 \%\end{array}$ \\
\hline Cowden syndrome & $\begin{array}{l}\text { mixed polyposis including } \\
\text { hamartomas }\end{array}$ & $\begin{array}{l}\text { PTEN mutation in } 80 \% \text { of cases; } \\
\text { autosomal dominant inheritance }\end{array}$ & $\begin{array}{l}\text { lifetime risk of developing colorectal } \\
\text { cancer approximately } 15 \% \text {; increased } \\
\text { risk of developing several types of } \\
\text { cancer, including cancers of the breast, } \\
\text { thyroid, and uterus; cumulative risk of } \\
\text { developing any cancer by age } 70 \text { is } \\
\text { approximately } 90 \%\end{array}$ \\
\hline
\end{tabular}

HNPCC $=$ Hereditary non-polyposis colon cancer (Lynch syndrome); FAP = familial adenomatous polyposis coli; MAP = MUTYHassociated polyposis; PJS = Peutz-Jeghers syndrome; JPS = juvenile polyposis syndrome; APC = adenomatous polyposis coli. years), small intestine, hepatobiliary tract, urinary tract, brain, and skin [8]. Regular colonoscopy with removal of precancerous polyps reduces the incidence of colorectal cancer. Therefore, the current recommendation is to perform colonoscopy every $1-2$ years beginning at ages between 20 and 25 years or 2-5 years before the earliest diagnosis in the family, whichever is earlier [13].

Patients with long-standing inflammatory bowel disease also have an increased risk of developing colorectal cancer [14]. The risk is essentially determined by the extent and duration of the inflammation in the colon. Risk is further increased in the case of coexistence of primary sclerosing cholangitis.

\section{Early Detection and Prevention}

Lifestyle modification, identification of individuals at risk, and removal of pre-neoplastic lesions are the most important measures for the prevention of colorectal cancer. Evidence from randomized trials shows a protective effect of several drugs including aspirin and hormone replacement therapy. A meta-analysis demonstrated a reduction in colorectal cancer-associated mortality among aspirin users with a latency of 10 years [15]. However, adverse effects including gastrointestinal bleeding preclude the use of aspirin for the primary prevention of colorectal cancer among the general population.

\section{Screening for Occult Blood}

Colorectal cancer commonly develops slowly over many years. The disease can be prevented if adenomas are detected and removed before they progress to cancer. Moreover, colorectal cancer is mostly curable if detected at early stages. Therefore, in contrast to the majority of other cancers, screening and early detection are excellent measures for the secondary prevention of colorectal cancer and associated death. Colorectal cancer-related morbidity and mortality can be reduced by screening programs. This has been demonstrated for stool tests detecting occult blood and flexible sigmoidoscopy. Non-invasive stool tests include gFOBTs (guaiac fecal occult blood tests) and FITs (fecal immunochemical tests for hemoglobin). These tests detect microscopic amounts of blood by targeting either heme (gFOBTs) or human globin (FITs). A metaanalysis of 4 large randomized controlled trials demonstrated that 
annual or biennial gFOBT screening led to an average $16 \%$ reduction in colorectal cancer-related mortality [16]. However, in 3 of the 4 studies, there was no effect on the incidence of colorectal cancer. The limited impact of gFOBT testing is due to its limited sensitivity for advanced adenoma with $10-15 \%$ and cancer with 30 $35 \%$. In contrast to gFOBTs, FITs are specific for human globin and have a higher sensitivity for advanced adenoma and cancer.

Qualitative FITs use an immunochromatographic approach similar to other point-of-care tests, e.g. home pregnancy tests. Quantitative tests are usually analyzed automatically using immunoturbidimetric methods. Some tests reach sensitivities of up to $25 \%$ for advanced adenoma and of $70 \%$ for cancer while maintaining a high specificity of $95 \%$ and higher $[17,18]$. To date, there are no randomized controlled trials available that demonstrate superiority of FITs over gFOBTs in terms of reducing colorectal cancerrelated mortality. However, considering the facts that both FIT and gFOBT identify components of erythrocytes, gFOBT has been demonstrated to reduce mortality, and performance of several FITs in terms of sensitivity and specificity is superior to gFOBT, it is very likely that fecal immunochemical testing has a superior effect on colorectal cancer incidence and mortality [19].

\section{Endoscopy}

Four randomized controlled trials have demonstrated that a single round of screening by flexible sigmoidoscopy resulted in a reduction in incidence (18-23\%) and mortality (22-31\%) of colorectal cancer [20-23]. Colonoscopy is the gold standard as a diagnostic tool for the colon and serves as the method of choice for the further work-up of positive stool tests and sigmoidoscopies, both in studies and in clinical routine. Cohort studies have demonstrated that colonoscopy in combination with polypectomy is able to reduce the incidence and mortality of colorectal cancer $[24,25]$. A recent study demonstrated that colonoscopy was able to reduce the risk of dying from colorectal cancer by $68 \%$ [26]. Randomized controlled trials demonstrating a reduction in incidence and mortality through colonoscopy screening are not yet available but are underway: NordICC (NCT00883792), COLONPREV (NCT00906997), SCREESCO (NCT02078804), and CONFIRM (NCT01239082). Results are expected between the years 2025 and 2034.

The emergence of interval cancers after initially negative screening colonoscopy is an important issue. Interval cancers are colorectal cancers that are diagnosed within 5 years of the last colonoscopy with either a negative result or followed by removal of all adenomas. There are three major reasons for the occurrence of interval cancers of the colon: i) colonoscopy missed advanced adenomas or cancer; ii) incomplete polypectomy; and iii) rapid de novo carcinogenesis. Prerequisites for avoiding interval cancers are a clean lavage of the colon, examination by an experienced colonoscopist, and total endoscopy reaching the cecum. A colonoscopist adenoma detection rate of $\geq 20$ has been demonstrated to be associated with the lowest number of interval colorectal cancers [27]. Complete polypectomy is essential to avoid adenoma recurrence [28]. After polypectomy, a surveillance endoscopy is recommended after 3-5 years depending on the size, number, and histology of the polyps removed. In the case of a piecemeal resection of an adenoma, the follow-up colonoscopy should be performed within 2-6 months.

\section{New Kids on the Block}

Several new tools for colorectal cancer screening have been developed and are currently being tested. These include computed tomographic colonography (CTC), magnetic resonance colonography (MRC), colon capsule endoscopy (CCE), and molecular stool and blood tests. CTC reaches sensitivities of $90 \%$ and more for adenomas $\geq 10 \mathrm{~mm}$ [29-31] and is therefore the second most sensitive tool for evaluating the colon. In contrast to CTC, MRC is not based on ionizing radiation but on magnetic resonance. In one study, sensitivities of MRC for adenomas $\geq 6 \mathrm{~mm}$ and advanced adenoma were 78.4 and $75 \%$, respectively [32]. CCE is a procedure that uses an ingestible capsule with a camera at both ends that produces images of the colon during transit. Second-generation CCE reaches a sensitivity of $88 \%$ for polyps $\geq 10 \mathrm{~mm}$ [33]. CTC, MRC, and CCE are first-round screening tests. While their sensitivities for significant findings are superior to stool tests, they all have two major drawbacks: i) one prerequisite similar to colonoscopy is colon lavage, and in the case of significant findings, a colonoscopy possibly preceded by a second lavage needs to be carried out; and ii) depending on the cut-off size of lesions for referral to colonoscopy, cost-efficiency might be a major issue.

Highly sensitive and specific, easily applicable, and broadly accepted first-round screening tests able to reliably select screenees with significant findings for colonoscopy would be ideal. Unfortunately, no such test is in sight yet. Newer stool and blood tests are based on the detection of DNA, RNA, or protein biomarkers derived from the tumors, either released into the circulation or shed into the stool. Based on the detection of circulating methylated Septin 9 DNA, the SEPT9 test has been demonstrated to have a sensitivity of $48 \%$ for colorectal cancer and of $11 \%$ for advanced adenoma which is not beyond that achievable with gFOBT and FIT [34]. A large study recruited 9,989 participants who provided a stool sample before colonoscopy that was analyzed using a panel of 4 DNA methylation markers and a FIT. This study demonstrated a sensitivity of $92.3 \%$ for colorectal cancer and of $42.4 \%$ for advanced adenoma for the DNA stool test plus FIT versus 72 and 23\% for the FIT alone [35]. However, taking into account the lower specificity of the DNA test, there is no clear advantage of the DNA test over the FIT [36].

\section{Diagnosis and Staging}

Stage at diagnosis is the most important prognostic factor. The 5 -year relative survival of patients diagnosed with colorectal cancer is $90 \%$ for patients with localized disease, $69 \%$ for patients with regional spread, and below $12 \%$ for patients with metastatic disease 
Table 2. Classification of colorectal cancers according to local invasion depth ( $\mathrm{T}$ stage), lymph node involvement ( $\mathrm{N}$ stage), and presence of distant metastases (M stage) [38]

\begin{tabular}{|c|c|}
\hline & Definition \\
\hline \multicolumn{2}{|c|}{ T stage } \\
\hline $\mathrm{Tx}$ & no information about local tumor infiltration available \\
\hline Tis & $\begin{array}{l}\text { tumor restricted to mucosa, no infiltration of lamina muscularis } \\
\text { mucosae }\end{array}$ \\
\hline $\mathrm{T} 1$ & $\begin{array}{l}\text { infiltration through lamina muscularis mucosae into submucosa, } \\
\text { no infiltration of lamina muscularis propria }\end{array}$ \\
\hline $\mathrm{T} 2$ & infiltration into, but not beyond, lamina muscularis propria \\
\hline T3 & $\begin{array}{l}\text { infiltration into subserosa or non-peritonealized pericolic or } \\
\text { perirectal tissue, or both; no infiltration of serosa or neighboring } \\
\text { organs }\end{array}$ \\
\hline T4a & infiltration of the serosa \\
\hline $\mathrm{T} 4 \mathrm{~b}$ & infiltration of neighboring tissues or organs \\
\hline \multicolumn{2}{|c|}{ N stage } \\
\hline $\mathrm{Nx}$ & no information about lymph node involvement available \\
\hline No & no lymph node involvement \\
\hline Nla & cancer cells detectable in 1 regional lymph node \\
\hline N1b & cancer cells detectable in 2-3 regional lymph nodes \\
\hline N1c & $\begin{array}{l}\text { tumor satellites in subserosa or pericolic or perirectal fat tissue, } \\
\text { regional lymph nodes not involved }\end{array}$ \\
\hline $\mathrm{N} 2 \mathrm{a}$ & cancer cells detectable in 4-6 regional lymph nodes \\
\hline $\mathrm{N} 2 \mathrm{~b}$ & cancer cells detectable in 7 or greater regional lymph nodes \\
\hline \multicolumn{2}{|c|}{ M stage } \\
\hline $\mathrm{Mx}$ & no information about distant metastases available \\
\hline M0 & no distant metastases detectable \\
\hline M1a & metastasis to 1 distant organ or distant lymph nodes \\
\hline M1b & $\begin{array}{l}\text { metastasis to more than } 1 \text { distant organ or set of distant lymph } \\
\text { nodes or peritoneal metastasis }\end{array}$ \\
\hline
\end{tabular}

[37]. Colorectal cancers are classified according to local invasion depth ( $\mathrm{T}$ stage), lymph node involvement ( $\mathrm{N}$ stage), and presence of distant metastases (M stage) (table 2) [38]. These TNM stages are combined into an overall Union Internationale Contre le Cancer (UICC) stage definition (table 3 ) which provides valuable prognostic information and basic therapeutic guidance. However, the individual patient's outcome and response to therapy are not predicted. Patients presenting with stenosing cancer who cannot be completely endoscopied prior to surgery can receive CTC, but should receive complete colonoscopy within 6 months after curative resection, because synchronous colorectal cancers occur in up to $4 \%$ of cases.

Two-thirds of all colorectal cancers are located in the colon and one-third in the rectum. Once the histological diagnosis of colorectal cancer is established, the local and distant extent of disease needs to be determined. About $20 \%$ of patients with newly diagnosed colorectal cancer have distant metastases. Basic examinations include an abdominal ultrasound and a chest X-ray. In the case of significant findings or limited informational value, a CT scan of the abdomen or thorax should be performed. It is standard practice in many institutions to perform standard abdominal, pelvic, and chest CTs prior to surgery in patients with stage II, III, and IV colorectal cancers. However, while this approach is debatable,
Table 3. Overall Union International Contre le Cancer stage classification of colorectal cancer [38]

\begin{tabular}{clll}
\hline & T & N & M \\
\hline Stage 0 & Tis & N0 & M0 \\
\hline Stage I & T1-T2 & N0 & M0 \\
\hline Stage II & T3-T4 & N0 & M0 \\
IIA & T3 & N0 & M0 \\
IIB & T4a & N0 & M0 \\
IIC & T4b & N0 & M0 \\
\hline Stage III & any & N+ & M0 \\
IIIA & T1-T2 & N1 & M0 \\
& T1 & N2a & M0 \\
IIIB & T3-T4a & N1 & M0 \\
& T2-T3 & N2a & M0 \\
& T1-T2 & N2b & M0 \\
IIIC & T4a & N2a & M0 \\
& T3-T4a & N2b & M0 \\
& T4b & N1-N2 & M0 \\
\hline IVA & any & any & M1a \\
IVB & any & any & M1b \\
\hline & & & any \\
\hline
\end{tabular}

certain findings such liver metastases not detected by ultrasound may alter the surgical approach. Sensitivity for liver metastases is highest for MRI followed by CT, and lowest for ultrasound [39].

CT imaging of the chest might be of more value in patients with rectal cancer since the liver is bypassed here and the venous drainage of the lower rectum is via the hemorrhoidal veins to the vena cava inferior. One major issue is the finding of indeterminate lesions in the lung in many patients, a minority of which finally turn out to be colorectal metastases. In a review of 12 studies including 5,873 patients who received a chest CT scan for staging, $9 \%$ were found to have indeterminate pulmonary nodules. Only $10.8 \%$ of these nodules finally turned out to be colorectal cancer metastases [40]. Positron emission tomography CT scanning is not a standard examination in preoperative staging but may be helpful in evaluating patients with metastatic disease for further surgery.

Accurate local staging is essential in patients with rectal cancer and a prerequisite for identifying patients who are candidates for chemoradiotherapy prior to surgery. The exact distance of the tumor from the anal verge is determined by rigid rectoscopy. Transrectal ultrasound (TRUS) and MRI are the most accurate imaging modalities for locoregional staging. Involvement of the circumferential resection margin (CRM) is an important independent prognostic factor in rectal cancer and can be most reliably determined preoperatively by MRI. Cancers that involve the CRM have a higher rate of pelvic recurrence after surgery alone [41]. If the mesorectal fascia is involved or if the tumor extends to a point that is within 1-2 $\mathrm{mm}$ of the mesorectal fascia, the CRM is threatened; these patients are appropriate candidates for neoadjuvant therapy.

\section{Disclosure Statement}

The author declares no competing interests. 


\section{References}

1 Ferlay J, Soerjomataram I, Ervik M, Dikshit R, Eser S, Mathers C, Rebelo M, Parkin DM, Forman D, Bray F: GLOBOCAN 2012 v1.0, Cancer Incidence and Mortality Worldwide: IARC CancerBase No. 11. Lyon, France, International Agency for Research on Cancer, 2013. globocan.iarc.fr (accessed January 31, 2016).

$\checkmark 2$ Center MM, Jemal A, Ward E: International trends in colorectal cancer incidence rates. Cancer Epidemiol Biomarkers Prev 2009; 18:621-630.

3 Robert Koch-Institut: Krebs in Deutschland 2011/2012, ed 10. Berlin, Robert Koch-Institut. $w w w$. krebsdaten.de (accessed January 31, 2016).

4 Platz EA, Willett WC, Colditz GA, Rimm EB, Spiegelman D, Giovannucci E: Proportion of colon cancer risk that might be preventable in a cohort of middle-aged US men. Cancer Causes Control 2000;11:579-588.

5 Nguyen SP, Bent S, Chen YH, Terdiman JP: Gender as a risk factor for advanced neoplasia and colorectal cancer: a systematic review and meta-analysis. Clin Gastroenterol Hepatol 2009;7:676-681.

6 Kolligs FT, Crispin A, Munte A, Wagner A, Mansmann U, Göke B: Risk of advanced colorectal neoplasia according to age and gender. PLoS ONE 2011; 6:e20076.

7 Brenner H, Hoffmeister M, Arndt V, Haug U: Gender differences in colorectal cancer: implications for age at initiation of screening. Br J Cancer 2007;96:828-831.

8 Kaminski MF, Polkowski M, Kraszewska E, Rupinski M, Butruk E, Regula J: A score to estimate the likelihood of detecting advanced colorectal neoplasia at colonoscopy. Gut 2014;63:1112-1119.

9 Butterworth AS, Higgins JP, Pharoah P: Relative and absolute risk of colorectal cancer for individuals with a family history: a meta-analysis. Eur J Cancer 2006;42: 216-227.

10 Aretz S: The differential diagnosis and surveillance of hereditary gastrointestinal polyposis syndromes. Dtsch Arztebl Int 2010;107:163-173.

11 Jasperson KW, Burt RW: APC-associated polyposis conditions; 1998 Dec 18 (updated 2014 Mar 27); in Pagon RA, Adam MP, Ardinger HH, Wallace SE, Amemiya A, Bean LJH, Bird TD, Fong CT, Mefford HC, Smith RJH, Stephens K (eds): GeneReviews ${ }^{\circledR}$ (Internet). Seattle, WA, University of Washington, 19932016. www.ncbi.nlm.nih.gov/books/NBK1345/ (accessed January 31, 2016).

12 Kohlmann W, Gruber SB: Lynch syndrome; 2004 Feb 5 (updated 2014 May 22); in Pagon RA, Adam MP, Ardinger $\mathrm{HH}$, Wallace SE, Amemiya A, Bean LJH, Bird TD, Fong CT, Mefford HC, Smith RJH, Stephens K (eds): GeneReviews ${ }^{\circledR}$ (Internet). Seattle, WA, University of Washington, 1993-2016. www.ncbi.nlm.nih.gov/ books/NBK1211/ (accessed January 31, 2016).

13 Engel C, Rahner N, Schulmann K, Holinski-Feder E, Goecke TO, Schackert HK, Kloor M, Steinke V, Vogelsang H, Möslein G, Görgens H, Dechant S, von Knebel Doeberitz M, Rüschoff J, Friedrichs N, Büttner R, Loeffler M, Propping P, Schmiegel W; German HNPCC Consortium: Efficacy of annual colonoscopic surveillance in individuals with hereditary nonpolyposis colorectal cancer. Clin Gastroenterol Hepatol 2010; 8:174-182.

14 Jess T, Rungoe C, Peyrin-Biroulet L: Risk of colorectal cancer in patients with ulcerative colitis: a meta-analysis of population-based cohort studies. Clin Gastroenetrol Hepatol 2012;10:639-645.

15 Rothwell PM, Fowkes FG, Belch JF, Ogawa H, Warlow CP, Meade TW: Effect of daily aspirin on long-term risk of death due to cancer: analysis of individual patient data from randomised trials. Lancet 2011;377: $31-41$.
Hewitson P, Glasziou P, Watson E, Towler B, Irwig L: Cochrane systematic review of colorectal cancer screening using the fecal occult blood test (hemoccult): an update. Am J Gastroenterol 2008;103:1541-1549.

17 Hundt S, Haug U, Brenner H: Comparative evaluation of immunochemical fecal occult blood tests for colorectal adenoma detection. Ann Intern Med 2009;150: 162-169.

18 Brenner H, Tao S: Superior diagnostic performance of faecal immunochemical tests for haemoglobin in a head-to-head comparison with guaiac based faecal occult blood test among 2,235 participants of screening colonoscopy. Eur J Cancer 2013;49:3049-3054.

19 Tinmouth J, Lansdorp-Vogelaar I, Allison JE: Faecal immunochemical tests versus guaiac faecal occult blood test: what clinicians and colorectal cancer screening programme organisers need to know. Gut 2015;64:1327-1337.

20 Schoen RE, Pinsky PF, Weissfeld JL, et al; PLCO Project Team: Colorectal-cancer incidence and mortality with screening flexible sigmoidoscopy. N Engl J Med 2012;366:2345-2357.

21 Segnan N, Armaroli P, Bonelli L, Risio M, Sciallero S, Zappa M, Andreoni B, Arrigoni A, Bisanti L, Casella C, Crosta C, Falcini F, Ferrero F, Giacomin A, Giuliani O, Santarelli A, Visioli CB, Zanetti R, Atkin WS, Senore C; SCORE Working Group: Once-only sigmoidoscopy in colorectal cancer screening: follow-up findings of the Italian Randomized Controlled Trial - SCORE. J Natl Cancer Inst 2011;103:1310-1322.

22 Holme Ø, Løberg M, Kalager M, Bretthauer M, Hernán MA, Aas E, Eide TJ, Skovlund E, Schneede J, Tveit KM, Hoff G: Effect of flexible sigmoidoscopy screening on colorectal cancer incidence and mortality: a randomized clinical trial. JAMA 2014;312:606-615.

23 Atkin WS, Edwards R, Kralj-Hans I, Wooldrage K, Hart AR, Northover JM, Parkin DM, Wardle J, Duffy SW, Cuzick J; UK Flexible Sigmoidoscopy Trial Investigators: Once-only flexible sigmoidoscopy screening in prevention of colorectal cancer: a multicentre randomised controlled trial. Lancet 2010;375:1624-1633.

24 Winawer SJ, Zauber AG, Ho MN, et al: Prevention of colorectal cancer by colonoscopic polypectomy. The National Polyp Study Workgroup. N Engl J Med 1993; 329:1977-1981

25 Zauber AG, Winawer SJ, O’Brien MJ, Lansdorp-Vogelaar I, van Ballegooijen M, Hankey BF, Shi W, Bond JH, Schapiro M, Panish JF, Stewart ET, Waye JD: Colonoscopic polypectomy and long-term prevention of colorectal-cancer deaths. N Engl J Med 2012;366:687696.

26 Nishihara R, Wu K, Lochhead P, Morikawa T, Liao X, Qian ZR, Inamura K, Kim SA, Kuchiba A, Yamauchi M, Imamura Y, Willett WC, Rosner BA, Fuchs CS, Giovannucci E, Ogino S, Chan AT: Long-term colorectal-cancer incidence and mortality after lower endoscopy. N Engl J Med 2013;369:1095-1105.

27 Kaminski MF, Regula J, Kraszewska E, Polkowski M, Wojciechowska U, Didkowska J, Zwierko M, Rupinski M, Nowacki MP, Butruk E: Quality indicators for colonoscopy and the risk of interval cancer. $\mathrm{N}$ Engl J Med 2010;362:1795-1803.

28 Pohl H, Srivastava A, Bensen SP, Anderson P, Rothstein RI, Gordon SR, Levy LC, Toor A, Mackenzie TA, Rosch T, Robertson DJ: Incomplete polyp resection during colonoscopy-results of the complete adenoma resection (CARE) study. Gastroenterology 2013;144: 74-80.
9 Pickhardt PJ, Choi JR, Hwang I, Butler JA, Puckett ML, Hildebrandt HA, Wong RK, Nugent PA, Mysliwiec PA, Schindler WR: Computed tomographic virtual colonoscopy to screen for colorectal neoplasia in asymptomatic adults. N Engl J Med 2003;349:2191-2200.

30 Johnson CD, Chen MH, Toledano AY, et al: Accuracy of CT colonography for detection of large adenomas and cancers. N Engl J Med 2008;359:1207-1217.

31 Graser A, Stieber P, Nagel D, Schäfer C, Horst D, Becker CR, Nikolaou K, Lottes A, Geisbüsch S, Kramer H, Wagner AC, Diepolder H, Schirra J, Roth HJ, Seidel D, Göke B, Reiser MF, Kolligs FT: Comparison of CT colonography, colonoscopy, sigmoidoscopy and faecal occult blood tests for the detection of advanced adenoma in an average risk population. Gut 2009;58:241-248.

32 Graser A, Melzer A, Lindner E, Nagel D, Herrmann K, Stieber P, Schirra J, Mansmann U, Reiser MF, Göke B, Kolligs FT: Magnetic resonance colonography for the detection of colorectal neoplasia in asymptomatic adults. Gastroenterology 2013;144:743-750.

33 Spada C, Hassan C, Munoz-Navas M, et al: Secondgeneration colon capsule endoscopy compared with colonoscopy. Gastrointest Endosc 2011;74:581-589.

34 Church TR, Wandell M, Lofton-Day C, Mongin SJ, Burger M, Payne SR, Castaños-Vélez E, Blumenstein BA, Rösch T, Osborn N, Snover D, Day RW, Ransohoff DF; PRESEPT Clinical Study Steering Committee, Investigators and Study Team: Prospective evaluation of methylated SEPT9 in plasma for detection of asymptomatic colorectal cancer. Gut 2014;63:317-325.

35 Imperiale TF, Ransohoff DF, Itzkowitz SH, Levin TR, Lavin P, Lidgard GP, Ahlquist DA, Berger BM: Multitarget stool DNA testing for colorectal-cancer screening. N Engl J Med 2014;370:1287-1297.

36 Brenner H, Werner S, Chen H: Multitarget stool DNA testing for colorectal-cancer screening. N Engl J Med 2014;371:184-185.

37 Siegel R, DeSantis C, Virgo K, Stein K, Mariotto A, Smith T, Cooper D, Gansler T, Lerro C, Fedewa S, Lin C, Leach C, Cannady RS, Cho H, Scoppa S, Hachey M, Kirch R, Jemal A, Ward E: Cancer treatment and survivorship statistics, 2012. CA Cancer J Clin 2012;62: 220-241.

38 Sobin LH, Gospodarowicz M, Wittekind C: TNM Classification of Malignant Tumours, 7th ed. New York, NY, Wiley-Blackwell, 2009.

39 Floriani I, Torri V, Rulli E, Garavaglia D, Compagnoni A, Salvolini L, Giovagnoni A: Performance of imaging modalities in diagnosis of liver metastases from colorectal cancer: a systematic review and meta-analysis. J Magn Reson Imaging 2010;31:19-31.

40 Nordholm-Carstensen A, Wille-Jörgensen PA, Jorgensen LN, Harling $\mathrm{H}$ : Indeterminate pulmonary nodules at colorectal cancer staging: a systematic review of predictive parameters for malignancy. Ann Surg Oncol 2013;20:4022-4030.

41 Taylor FG, Quirke P, Heald RJ, Moran BJ, Blomqvist L, Swift IR, Sebag-Montefiore D, Tekkis P, Brown G; Magnetic Resonance Imaging in Rectal Cancer European Equivalence Study Study Group: Preoperative magnetic resonance imaging assessment of circumferential resection margin predicts disease-free survival and local recurrence: 5-year follow-up results of the MERCURY study. J Clin Oncol 2014;32:34-43. 